\title{
Analisis Pengembangan Potensi Obyek Wisata Pantai di Kabupaten Serdang Bedagei
}

\section{Analysis of the Development of Potential Coastal Tourism objects in Serdang Bedagei District}

\author{
Maringan Sirait \& Mbina Pinem* \\ Jurusan Pendidikan Geografi, Fakultas Ilmu Sosial, Universitas Negeri Medan, Indonesia
}

Diterima: Februari 2019; Disetujui: April 2019; Dipublish: Juni 2019.

\begin{abstract}
Abstrak
Penelitian ini bertujuan untuk mengetahui potensi pariwisata di Kabupaten Serdang Bedagai pada Objek Lokasi Tujuan Wisata Pantai (OLTWP). Metode penelitian survey deskipsi dari data primer dan data sekunder. Data primer diperoleh menggunakan alat bantu angket observasi yang telah dipersiapkan. Pengamatan dan observasi kondisi wilayah objek untuk mengetahui potensi wisata secara langsung di lapangan. Pengamatan yang dilakukan menyangkut potensi atraksi wisata alam, flora dan fauna, serta lanskap kawasan, transportasi dan aksesibiltas serta objek penunjang kebutuhan pengunjung. Analisis data terhadap potensi obyek wisata metode skoring pada setiap variabel. Variable nilai skor tinggi mendukung pengembangan obyek wisata dan nilai skor rendah kurang mendukung kemudian dilakukan analisis SWOT, guna mengetahui kekuatan dan kelemahan internal, kesempatan dan ancaman eksternal dari ke 16 lokasi berpotensi tinggi dengan urutan tertinggi hingga potensi sangat kurang yaitu objek wsiata pantai: 1) Theme Park, 2) Kiang, 3) Mutiara, 4) Lestari, 5) Gudang Garam, 6) Permai Indah, 7) Sialang Buah, 8) Wong Rame, 9) Sri Mersing, 10) Romantis Bay, 11) Cemara Kembar, 12) Kuala Putri, 13) Pematang Mantik, 14) Nipah Indah, 15) Hutan Mangrove (Kampoeng Nipah), 16) Sentang, dan 17) Objek Wisata Pulau Berhala yang berada di bawah pengawasan TNI, dan sekaligus sebagai lokasi penangkaran satwa penyu.

Kata Kunci: Pengembangan, Potensi, Persepsi Masyarakat
\end{abstract}

\begin{abstract}
This study aims to determine the potential of tourism in Serdang Bedagai Regency on Objects of Coastal Tourism Destinations (OLTWP). Method of descriptive survey research from primary data and secondary data. Primary data obtained using a tool that has been prepared observation questionnaire. Observation and observation of the condition of the object area to find out the tourism potential directly in the field. Observations made regarding the potential of natural tourist attractions, flora and fauna, as well as regional landscapes, transportation and accessibility as well as objects supporting visitor needs. Analysis of data on the potential of tourism scoring methods on each variable. Variable high score values support the development of tourism objects and low score scores are less supportive then SWOT analysis is carried out, in order to find out internal strengths and weaknesses, opportunities and threats from 16 high potential locations with the highest order to very low potential, namely coastal objects: 1) Theme Park, 2) Klang, 3) Mutiara, 4) Sustainable, 5) Gudang Garam, 6) Permai Indah, 7) Sialang Buah, 8) Wong Rame, 9) Sri Mersing, 10) Romantis Bay, 11) Twin Fir, 12) Kuala Putri, 13) Pematang Mantik, 14) Nipah Indah, 15) Mangrove Forests (Kampoeng Nipah), 16) Sentang, and 17) Berhala Island that are under the supervision of the Tentara Nasional Indonesia, and at the same time as a location for captive turtles.
\end{abstract}

Keywords: Development, Potential, Community Perception

How to Cite: Sirait, M. \& Pinem, M. (2019) Analisis Pengembangan Potensi Obyek Wisata Pantai di Kabupaten Serdang Bedagei. JUPIIS: Jurnal Pendidikan Ilmu-ilmu Sosial: 11 (1): 29-45.

*Corresponding author: ISSN 2085-482X (Print)

E-mail: pinemmbina@gmail.com ISSN 2407-7429 (Online) 


\section{PENDAHULUAN}

Sektor pariwisata sebagai kegiatan perekonomian telah menjadi andalan yang potensial dan perioritas pengembangan bagi sejumlah negara, terlebih bagi negara berkembang seperti Indonesia. Ada beberapa alasan yang mendasari sektor pariwisata dijadikan sebagai sektor andalan dalam pembangunan nasional adalah keinginan untuk meningkatkan kepariwisataan yang ada di Indonesia.

Indonesia memiliki potensial wilayah laut yang luas. Dengan daya tarik wisata yang cukup besar, banyaknya keindahan alam, aneka warisan sejarah budaya dan kehidupan masyarakat (etnik). Keinginan untuk meningkatkan kepariwisataan Indonesia pada dasarnya disebabkan beberapa faktor diantaranya: 1) Makin berkurangnya minyak bumi sebagai penghasil devisa; 2) Prospek pariwisata yang tetap memperlihatkan kecenderungan meningkat secara konsisten; 3) Besarnya potensi yang dimiliki bagi upaya pengembangan pariwisata di Indonesia (Spillane, 1994).

Menghadapi era globalisasi telah terjadi persaingan merebut devisa dari sektor nonmigas semakin ketat, tidak terlepas pada sektor pariwisata yang menjadi andalan utarna. Beda dengan industri migas yang berdasar pada bahan bakar fosil. Pariwisata tidak tergantung dari sumberdaya yang makin berkurang justru sebaliknya.

Pariwsiata di Indonesia merupakan salah satu penunjang perekonomian yang memiliki prospek yang cerah, tetapi hingga saat ini belum memperlihatkan perannya yang sesuai dengan harapan dalam proses pembangunan di Indonesia. Prospek pariwisata dimasa yang akan datang terutama bagi Indonesia sangatlah menjanjikan bahkan sangat memberi peluang besar, terutama apabila dilihat dari banyaknya angka wisatawan internasional (inbound tourism) diperkirakan WTO (World Tourism Organization) mencapai 1,046 milyar orang (2010) dan 1,602 milyar orang (2020). Agar pariwisata dapat berkembang, harus berupaya meningkatkan lingkungan dan memelihara keseimbangan kondisi lingkungan hidup beserta kelestariannya, seperti yang diamanatkan Undang-Undang No 4 tahun 1982 tentang: Ketentuan Pokok Pengelolaan Lingkungan Hidup pada Pasal 1 Ayat 1, yaitu: Lingkungan hidup adalah kesatuan ruang dengan semua daya, keadaan dan mahkluk hidup, termasuk di dalamnya manusia dan perilaku yang mempengaruhi kelangsungan perikehidupan dan kesejahteraan manusia serta mahluk hidup lainnya.

Dengan demikian pembangunan sektor pariwisata harus tetap menjaga kelestarian lingkungan hidup. Pembangunan pariwisata memiliki masalah ekologi yang sebagian diantaranya tidak dapat pada tipe aktivitas ekonomi lainnya. Sumberdaya lingkungan yang digunakan untuk pariwisata hams dikelola sebaik-baiknya agar dapat menarik pengunjung karena keindahannya yang menonjol, karena ada kemungkinan (probability) untuk berkreasi atau karena penting untuk pendidikan.

Dalam ekologi pariwisata, perhatian sering tertuju pada kemampuan suatu daerah untuk menerima kedatangan para wisatawan, sehingga keinginan untuk mengembangkan sektor pariwisata, dan pada dasarnya suatu daerah memiliki suatu kemampuan tertentu disebut daya dukung lingkungan (Muta'ali, 2013a). Kusumonagoro (1999 dan Muta'ali, 2013b), menjelaskan bahwa daya dukung lingkungan pariwisata ditentukan dua faktor yaitu tujuan wisatawan dan faktor biofisik lokasi pariwisata. Tujuan dari pariwisata itu sendiri adalah untuk mendapatkan rekreasi, yaitu suatu keinginan untuk dapat menciptakan kembali atau memulihkan kekuatan diri, baik fisik maupun spritual, maka banyak macam kegiatanyang mungkin dapat 
dilakukan para wisatawan bergantung pada tujuannya masing-masing.

Faktor biofisik dapat mempengaruhi kuat-tidaknya ekosistem akan sangat mempengaruhi besar kecilnya daya dukung tempat wisata tersebut. Ekosistem yang kuat mempengaruhi daya dukung yang tinggi, yaitu dapat menerima jumlah wisatawan dalam jumlah besar. faktor biofisik yang mempengaruhi daya dukung lingkungan bukan faktor alamiah saja, faktor buatan manusia juga sangat besar pengaruhnya seperti sarana pariwisata yang ada di lokasi dengan tetap memperhatikan ekosistem lingkungan dan wilayah (Mutha'ali, 2013b). Sarana pariwisata merupakan faktor penentu daya dukung antara lain jalan dan tempat penginapan (akomodasi). Daya dukungan lingkungan tidak hanya dilihat dan sarana pelayanan wisatawan saja melainkan juga pada kemampuan lingkungan itu sendiri untuk mendukung sarana yang ada.

Perkembangan dan pertumbuhan sektor pariwisata perlu diantisipasi agar perkembangannya tetap pada daya dukungnya. Penilaian tingkat perkembangan pariwisata suatu daerah sangat penting guna menentukan prioritas dan strategi dalam pengembangannya, agar pengembangan sektor parawisata sangat perlu ditangani secara serius. Kepariwisataan yang dikelola secara profesional, hasilnya dapat memberikan sumbangan pendapatan asli daerah (PAD) pada wilayah tersebut.

Industri pariwisata merupakan suatu susunan organisasi, baik pemerintah maupun swasta, yang terkait dalam pengembangan, produksi dan pemasaran produk suatu layanan untuk memenuhi kebutuhan dari orang yang berpergian (Hadinoto, 1996). Industri pariwisata sifatnya kompleks yang harus didukung oleh sektor-sektor yang lain. Orisinalitas alam suatu daerah pariwisata dapat ditingkatkan nilainya jika paket-paket wisata dirangkum dan dikemas secara professional dan manajemen yang baik dengan daya dukung sarana dan prasarana yang memadai. Usaha pariwisata adalah kegiatan yang bertujuan menyelenggarakan jasa pariwisata atau menyediakan atau mengusahakan obyek dan daya tarik wisata, usaha barang pariwisata, dan usaha lain yang terkait dibidang tersebut sesuai dengan bunyi UU Nomor 9 tahun 1990 tentang: kepariwisataan, Pasal 1 Ayat 5.

Di era otonomi daerah saat ini, peran pemerintah daerah dalam pembangunan diberi keleluasaan dalam mengelola potensi daerahnya masing-masing, termasuk salah satunya adalah sektor pariwisata. Kebijakan pemerintah daerah dalam pembangunan pariwisata sangat penting perannya dalam memajukan industri pariwisata yang ada di daerah itu. Sebagai pelaku utama, pemda dan pihak yang terkait harus dapat bekerja secara lintas sektoral. Kebijakan pemerintah daerah juga memiliki peranan penting dalam menunjang keberhasilan pembangunan pariwisata secara harus benar-benar mampu dalm mengoptimalkan potensi pariwisata diwilayahnya masing-masing.

Kabupaten Serdang Bedagai adalah salah satu daerah di Provinsi Sumatera Utara kaya potensi pariwisata pantai, wisata budaya, wisata alam, wisata pendidikan dan wisata lain yang cukup berpotensi untuk dikembangkan, mengingat Kabupaten Serdang UU Nomor 9 tahun 1990 tentang: kepariwisataan Serdang Bedagai mempunyai wilayah berjulat dari pantai sampai ke dataran tinggi. Obyek wisata ini ada yang sudah berkembang, sedang berkembang maupun yang berpotensi untuk dikembangkan.

Dari 21 obyek wisata yang ada di Kabupaten Serdang Bedagai, wisata alam masih menjadi tumpuan dan nomor satu di kabupaten ini yaitu sebanyak 17 lokasi khusus objek wisata pantai. Jenis wisata alam yang ada di Kabupaten Serdang Bedagai diantaranya, obyek wisata: 1) Pantai Mutiara, 2) Pantai Gudang Garam, 
3) Pantai Wong Rame, 4) Pantai Permai Indah, 5) Pantai Lestari, 6) Pantai Theme Park Pantai Cermin, 7) Kuala Putri, 8) Sri Mersing, 9) Mantik, 10) Kampoeng Nipah, 11) Cemara Kembar, 12) Pantai Hutan Mangrove, 13) Pantai Romantis, 14) Pantai Klang, 15) Pantai Sialang Buah, 16) Pantai Sentang, 17) Pulau Berhala, 18) Pamandian Alam Ancol, 19) Air Terjun Sempuma Within, 20) Pemandian Batu Nongol, dan 21) Kampung Bali di desa Pregajahan.

Jumlah obyek wisata alam yang ada, belum semuanya berkembang secara maksimal, disebabkan banyak faktor, seperti dikarenakan obyek-obyek tersebut jauh dari ibukota kabupaten, ibukota propinsi, aksesibilitas yang masih kurang mendukung sehingga perkembangannya belum seperti yang diharapkan, atau kondisi fisik alam atau pantai itu sendiri kurang mendukung ditambah pula sarana prasarana menuju lokasi yang tidak memadai berdampak pengunjung tidak tertarik berkunjung. Salah satu obyek wisata alam yang paling berpeluang dan potensial untuk dikembangkan di kabupaten ini adalah jenis obyek wisata pantai yang ada di Kecamatan Pantai Cermin di Desa Kota Pari, Desa Pantai Cermin Kanan dan Pulau Berhala dengan 3 pulau yang ada di sekitarnya yang cukup bagus tidak masuk dalam penelitian ini, karena wilayah ini merupakan wilayah yang dilindungi dan sebagai wilayah pertahanan TNI Angkatan Laut.

Secara geografis, yang dimaksudkan pantai dalam penelitian ini adalah wilayah yang tennasuk ke wilayah daratan sampai batas habisnya pengaruh perairan laut dan keperairan sampai batas areal yang masih dipengaruhi daratan (Fandeli, 2002). Pantai merupakan obyek wisata alam yang sangat ramai dikunjungi baik pengunjung lokal maupun mancanegara. Di Kabupaten Serdang Bedagai ada tiga pantai yang cukup terkenal yakni Pantai Kecamatan Pantai Cermin, Pantai Klang dan Pulau Berhala (masih belum dikelola dengan sempurna). Dan ketiga objek wisata pantai ini, apabila dilihat perkembangan dan potensi yang ada kiranya objek wisata pantai jumlah pengunjungnya ramai, walaupun hanya pengunjung lokal. Di hari Minggu dan hari libur tertentu, keramaian orang dan atraksi belum jelas tampak di pantai ini. Maksudnya dengan atraksi wisata yang ada diidentifikasikan dalam suatu penelitian, dan telah dikembangkan menjadi atraksi wisata yang berkualitas dan memiliki aksesibilitas yang baik seperti yang dikatakan Hadinoto (1996).

Dengan banyaknya atraksi dan daya tarik yang ada di lokasi obyek wisata pantai seperti objek wisata di Pantai Cermin menjadi andalan pemerintah daerah untuk meningkatkan Pendapatan Asli Daerah (PAD). Walaupun obyek wisata yang mempunyai areal tidak begitu luas yang letaknya jauh dan ibukota kabupaten, tetapi lebih dekat dari ibukota propinsi (daya tarik) Kota Medan dengan kondisi prasarana jalan yang sudah baik dan tersedia sarana transportasi yang ramai, ramai untuk menjangkau wisata dan prasarana yang memadai merupakan daya tarik wisatawan untuk datang ke daerah ini.

Mengingat cukup banyak lokasi objek wisata pantai di Kabupaten Serdang Bedagai maka perlu dilakukan penelitian di obyek wisata ini dan membandingkannya satu dengan yang lain untuk dapat ditetapkan sebagai objek wisata pantai unggulan pengembangannya dalam rangka meningkatkan Pendapatan Asli Daerah (PAD) Kabupaten Serdang Bedagai dan sekaligus melihat potensi yang masih perlu mendapat perhatian serius.

\section{METODE PENELITIAN}

Penelitian untuk kajian obyek wisata pantai, menggunakan penelitian survey deskriptif, bertujuan untuk mendeskripsikan atau melukiskan realitas sosial yang ada dalam masyarakat, untuk memperoleh fakta dari gejala yang ada dan 
mencari keterangan secara faktual yaitu tentang kondisi wilayah, kondisi sosial dan ekonomi (Mantra dan Kasto, 2008 dalam Singarimbun 1989). Metodologi survey deskriptif menggunakan data primer dalam menggali informasi dan data sekunder sebagai data penunjang. Objek penelitian adalah kawasan wisata pantai yang ada di kecamatan Kabupaten Serdang Bedagai. Pengamatan dan observasi tentang kondisi wilayah objek untuk mengetahui potensi wisata yang belum termanfaatkan secara optimal oleh masyarakat sekitar dalam menunjang pengembangan dan meningkatkan kesejahteraan. Pengamatan yang dilakukan menyangkut potensi atraksi wisata alam, flora dan fauna, serta lanskap kawasan.

Pengamatan terhadap pengunjung objek dan masyarakat lokal dimaksudkan untuk mengetahui persepsi dan partisipasi masyarakat terhadap pengembangan ODTW dan keinginan wisatawan tentang model pengembangan objek.

Lokasi penelitian di kawasan wisata pantai di kecamatan-kecamatan Kabupaten Serdang Bedagai (pada lokasi objek wisata pantai Kecamatan Pantai Cermin, dan wisata pwisata pantai Kecamatan Perbaungan). Untuk mencapai tujuan penelitian di atas, data yang dikumpulkan terbagi menjadi data primer dan data sekunder. Data primer yaitu: Data potensi objek wisata, data persepsi masyarakat, dan strategi pengembangan. Untuk memperkaya data hasil lapangan, dikumpulkan data sekunder yang berasal dan berbagai literatur yang berhubungan dengan lokasi penelitian, tema penelitian, melalui studi pustaka dan Profil Wilayah, serta Renstra Kabupaten Serdang Bedagai.

Langkah yang ditempuh dalam penelitian ini adalah: 1) Pemilihan daerah penelitian; 2) Pengumpulan data; 3) Pemilihan sampel; 4) Variabel Penelitian; 5) Analisis data. Data primer diperoleh dengan melakukan observasi, dan kondisi ini merupakan rangkaian awal dalam mengamati kondisi obyek dan dalam rangka melengkapi data yang diperoleh. Selain observasi juga dilaksanakan suatu wawancara yang terstruktur, yakni dengan cara menggunakan kuesioner. Kuesioner ini dilakukan terhadap wisatawan yang berhubungan dengan asal, umur, jenis kelamin, tingkat pendidikan, jenis pekerjaan, tingkat pendapatan. Data primer diperoleh dengan dilakukan sendiri observasi langsung lapangan dengan menggunakan alat bantu angket yang telah dipersiapkan terlebih dahulu. Kondisi ini merupakan rangkaian awal dalam mengamati kondisi obyek dan dalam rangka melengkapi data yang diperoleh. Wawancara juga dilakukan secara terstruktur dengan cara menggunakan kuesioner, terhadap wisatawan yang berhubungan dengan asal, umur, jenis kelamin, tingkat pendidikan, jenis pekerjaan dan tingkat pendapatan dan persepsi masyarakat terhadap obyek.

Data sekunder dilakukan dengan cara studi pustaka, mencari data melalui dinas atau instansi yang terkait dengan penelitian yang sedang dilakukan. Jenis dan sumber data yang dikumpulkan dan digunakan dalam penelitian ini. Penelitian ini menggunakan sebagian dari populasi yang ada, sehingga dimaksudkan dapat menggambarkan sifat dan populasi yang diteliti. Sampel yang sama memiliki kesempatan dan peluang yang sama untuk dipilih. Oleh karena itu diperlukan metode yang tepat dan akurat, yaitu survei lapangan yang diharapkan mampu memberikan kesesuaian dengan ciri-ciri populasi dan tujuan penelitian itu. Untuk mengetahui profil dan pendapat dan wisatawan, maka populasi yang diperlukan adalah wisatawan itu sendiri. Untuk mengetahui pendapat/persepsi masyarakat terhadap obyek wisata pantai di lokasi hanya dilakukan wawancara terhadap beberapa tokoh masyarakat, sebagian penduduk di sekitar pantai dan pihak pengelola pantai. 
Data yang dipakai dalam penelitian ini menggunakan data primer yang diperoleh dengan menggunakan kuesioner yang ditujukan pada wisatawan dan wawancara langsung terhadap sebagian masyarakat disekitar obyek wiasata pantai di lokasi. Wawancara ini dilakukan untuk mendapatkan informasi eksternal terkait faktor peluang dan penghambat pengembangan objek wisata pantai di Kabupaten Serdang Bedagai.

Teknik yang dipakai dalam pengambilan sampel terhadap wisatawan adalah quota sampling dengan cara aksidentil. Pengambilan sampel dengan cara memilih sampel dan populasi wisatawan yang datang ke obyek wisata pantai dan mengambil siapa saja yang berada ditemui di lokasi. Pengambilan sampel ini dilakukan dengan asumsi jumlah populasi tidak diketahui dengan pasti dan jumlah pengunjung ke obyek wisata pantai masih sedikit. Sistem pengambilan data dilakukan pada hari libur (25 orang) sebanyak dua kali dan kerja (25 orang) juga dua kali, untuk membandingkan jumlah pengunjung dan karakteristik wisatawan yang datang pada lokasi yang berbeda. Jadi jumlah keseluruhan rsponden sebanyak 100 responden. Cara pengambilan data yang dilakukan ini terhadap responden dengan menghindari pengambilan lebih dari dua responden pada kelompok yang sama, bertujuan menghindari jawaban yang sama.

Teknik pengambilan sampel pada masyarakat dengan menggunakan wawacara secara sederhana terhadap sebagian masyarakat saja (tokoh masyarakat, sebagian penduduk biasa dan pihak pengelola pantai). Jumlah sampel yang diambil untuk wisatawan sebanyak 50 orang dalam bentuk kuesioner, dengan asumsi cukup untuk menggambarkan profil dan karakteristik wisatawan yang berkunjung ke obyek wisata ini. Selain hal tersebut juga dilakukan wawancara langsung terhadap masyarakat, dengan harapan dapat diketahui persepsi dari masyarakat yang ada di sekitar obyek wisata tersebut. Pengambilan sampel ini dilakukan dengan tujuan untuk mengetahui pendapat wisatawan dan masyakat setempat tentang obyek wisata pantai di lokasi.

Infonnasi yang diperoleh dan informan yang sangat mengetahui permasalahan ditentukan dengan purposive snowbowll sampling. Cara ini pada awalnya ditentukan sejumlah kecil, kemudian akan bekembang sesuai dengan kebutuhan data sehingga data yang terkumpul lengkap sesuai dengan tujuan penelitian. Orang yang dimaksud sebagai informan adalah Kepala Dinas Pariwisata Kabupaten Serdang Bedagai.

Sesuai dengan penelitian yang berjudul Analisis Pengembangan Potensi Pariwisata Pantai Di Kabupaten Serdang Bedagai, maka variabel yang dipakai untuk menilai potensi suatu wilayah, dalam hal ini potensi obyek wisata sebagai unit analisis. Variabel-variabel tersebut dapat digunakan untuk menilai potensi yang ada, sehingga pengembangan potensi wisata dapat diketahui dan mempermudah jalannya pengembangan wisata ini. Pemilihan variabel dilakukan dengan melihat faktor-faktor yang berpengaruh terhadap pengembangan potensi obyek wisata tersebut.

Untuk mengetahui potensi flora dilakukan inventarisasi terhadap jenis dan jumlah individu dari flora yang ada di kawasan objek wisata pantai. Inventarisasi dilakukan dengan membuat beberapa plot pada jalur pengamatan dengan pertimbangan faktor-faktor kemudahan pencapaian dari jalur yang diambil sebagai sampel. Pengambilan data flora dilakukan dengan metode purposive sampling yaitu memperhatikan kondisi estetika geofisik lokasi setempat.

Metode yang digunakan dalam inventarisai fauna dilakukan melalui penjelajahan (renaissance survey) pencatatan terhadap seluruh fauna yang 
ditemukan di lokasi objek wisata berdasarkan jejak kaki, suara, kotoran, maupun informasi masyarakat lokal. (Alikodra, 1999). Potensi objek ekowisata yang tinggi mempunyai nilai keanekaragaman jenis fauna yang tinggi.

Untuk mengetahui potensi Lanskap dilakukan pengamatan potensial visual dengan mengacu pada metode Leopold yang dikembangkan oleh Bureau of Land Management (1986). Titik amatan dipilih pada tempat-tempat yang mempunyai potensi untuk dikembangkan. Unsur landskap, skor, dan kriteria yang diamati, disajikan dalam tabel.

Inventarisasi komponen produk wisata adalah kegiatan untuk mengetahui berbagai hal yang berhubungan dengan keberadaan objek wisata meliputi ODTW, amenitas, utilitas, aksesibiltas. Setiap komponen yang diinventarisasi selanjutnya dicatat jenis komponennya, deskripsi, jumlah, kualitas dan keterangan lain yang terkait dengan wisatawan.

Penelitian terhadap pengunjung dimaksudkan untuk mengetahui karakteristik pengunjung dan persepsi pengunjung tentang ODTW yang berkunjung. Pemilihan sampel pengunjung digunakan teknik accidental sampling, yaitu pengunjung yang di temui di lokasi penelitian yang kemudian diberi kuisioner dan juga diwawancarai. Penetapan jumlah wisatawan sebagai responden dihitung dengan memperhatikan tingkat ketelitian dan jumlah populasi wisatawan yang ada dalam kawasan kemudian dihitung menggunakan rumus Sevilla (Fandeli, 2002).

Informasi yang diperoleh dari pengunjung meliputi pola kunjungan, asal pengunjung, motivasi, lama kunjungan, cara berkunjung, dan persepsi pengunjung terhadap pengembangan dari objek wisata.

Penelitian dilakukan pada masyarakat lokal dimaksudkan untuk mengetahui persepsi masyarakat tentang keberadaan objek dan kondisi potensi wisata pantai yang belum termanfaatkan secara maksimal. Lingkup wilayah adalah perkampungan objek wisata pantai tersebut berada. Penggunaan sampel masyarakat menggunakan metode purposive sampling, dengan pertimbangan yang menjadi sampel adalah masyarakat yang terlibat langsung dengan objek wisata.

Data dan informasi yang dikumpulkan, baik berdasarkan hasil penelitian lapangan, maupun dari instansi terkait akan diklasifikasikan, dideskripsikan, dianalisis dan diinterpretasikan secara kualitatif dan kuantitatif. Data yang dianalisis secara kualitatif meliputi kondisi wilayah, letak, luas, kondisi lahan, kondisi sosial ekonomi, budaya, hubungan masyarakat dengan objek wisata, persepsi masyarakat tentang objek wisata. Data kemudian disajikan dalam bentuk tabel, uraian, atau grafik serta dianalisis secara deskriptif. Data yang dianalisis secara kuantitatif adalah potensi flora fauna, dan kesesuaian atraksi wisata.

Setelah melakukan penilaian pengharkatan potensi fisik landskap daya tarik objek wisata, transportasiaksesibiltas dan fasilitas penunjang objek wisata dilakukan analisis SWOT. Menggunakan analisis Strengths Weaknesses, Opportunites Threats (SWOT) bertujuan untuk menetapkan strategi pengembangan objek wisata pantai. Teknik analisis SWOT digunakan untuk mengetahui kekuatan dan kelemahan internal, kesempatan atau yang menjadi peluang serta apa yang menjadi kelemahan atau ancaman eksternal pada objek kajian. Pertama yang harus dilakukan adalah melakukan penilaian terhadap potensi dari setiap objeknya yang ada. Analisis SWOT dilakukan terhadap selunth objek yang ada dengan membuat lembar kerja berisi persilangan dari empat bagian yang masig-masing terdiri dari kekuatan, kelemahan, kesempatan dan ancaman. Dan hasil observasi yang telah dilakukan (Lampiran 1, dan 2) dapat 
diketahui menjadi kekuatan, kelemahan, kesempatan dan ancaman ditiap objek wisata pantai tersebut. Kesempatan dan peluang maupun ancaman dan tantangan bersifat melengkapi dari anaslisa internal yang didapatkan dari hasil wawancara dan studi dokumen.

\section{HASIL DAN PEMBAHASAN Objek Wisata Pantai}

Objek wisata pantai yang ada di Kabupaten Serdang Bedagai tergolong pada kegiatan pada bibir pantai, di daratan yang berdekatan atau berbatasan dengan air, karena para pengunjung lebih dominan melakukan kegiatan seperti yang dikatakan Wall (2009) yaitu berjemur, menikmati pemandangan, bersantai dan mengkomsumsi makanan.

Ke 16 objek wisata pantai yang ada di Kabupaten Serdang Bedagai Wisata belum dapat dikatakan Objek Wisata Maritim atau Bahari (wisata tirta), karena kegiatan wisata maritim (bahari) belum banyak dilakukan pengunjung berkaitan dengan kegiatan olahraga air seperti di danau, pantai, teluk, atau laut, memancing, berlayar, menyelam sambil melakukan pemotretan, kompetisi berselancar, balapan mendayung, melihat taman laut dengan pemandangan indah di bawah permukaan air. Penyebaran objek wisata pantai yang ada di Kabupaten Serdang Bedagai terdapat di 17 lokasi dan penyebarannya tidak merata tergambar pada Gambar 3, terkelompok di 3 wilayah kecamatan yaitu: 1) Kecamatan Pantai Cermin, 2) Kecamatan Perbaungan, dan 3) Kecamatan Teluk Mengkudu. Ketujuh belas objek wisata tergolong kepada objek wisata di Kabupaten Serdang Bedagai tergolong wisata maritime tapi tidak sepenuhnya, namun ada pula wisata budaya.

Hasil penelitian melalui pemberian scoring terhadap aspek variable objek wisata pantai yang ada di 16 terlihat pada Tabel 6A dan Tabel 6B. Objek wisata pantai Pulau Berhala tidak ikut dianalisa karena belum merupakan objek wisata pantai untuk umum. Pulau Berhala merupakan wisata maritime atau bahari dan merupakan daerah khusus penangkaran penyu dan kawasan TNI dan daerah ini cocok untuk objek ekowisata. Secara umum potensi objek wisata pantai yang ada di Kabupaten Serdang Bedagai terkelompok dalam objek wisata pantai berpotensi sedang.

Ke 16 objek wisata pantai di Kabupaten Serdang Bedagai menyebar tidak merata, mengelompok dan sangat berdekatan satu dengan lain serta mengelompok, tergambar pada Gambar Peta 3. Persebaran dari ke 16 objek wisata yang ada di Kabupaten Serdang Bedagai tergambar ke dalam 3 kelompok yaitu; Pertama yaitu objek wisata pantai a) Mutiara, b) Gudang Garam, c) Wong Rame, d) Permai Indah, e) Lestari, dan f) Theme Park, Kedua: yaitu objek wisata a) Kuala Putri, b) Sri Mersing, dan c) Pematang Mantik, dan Ketiga: yaitu objek wisata pantai a) Nipah Indah, b) Cemara Kembar, c) Hutan Mangrove, d) Romantis Bay, e) Kiang, f) Sialang Buah, dan g) Sentang.

\section{Analisa SWOT}

Analisa SWOT yang dilakukan dengan membuat lembar kerja berisikan dari persilangan dari empat bagian yang masing-masing bagian terdiri dari Kekuatan (Strength), Kelemahan (Weakness), Kesempatan (Opportunity) dan Tantangan/Ancaman (Threat). Hasil observasi yang telah dilakukan pada objek wisata pantai di Kabupaten Serdang Bedagai dapat diketahui yang menjadi kekuatan, kesempatan dan tantangan sebagai faktor internal, peluang dan kelemahan dari masing-masing objek wisata pantai sebagai faktor eksternal. Hasil analisis SWOT yang dilakukan terlihat pada Tabel 7 menunjukkan hasil belum seiring dengan yang dikatakan Yoeti (2004) yaitu untuk dapat melakukan perencanaan pariwisata perlu diketahui aspek yang berpengaruh positif (kekuatan 
darn kesempatan) maupun yang negative (kelemahan dan tantangan) dalam pengembangan pariwisata, yaitu: 1) Wisatawan (tourist), 2) Pengangkutan (transportations), 3) Atraksi/obyek wisata (attractions), 4) Fasilitas pelayanan (servis facilities), dan 5) Informasi dan promosi (imformations).

Tabel 7 : Hasil Analisis SWOT terhadap Objek Wisata Pantai Di Kabupaten Serdang Bedagai

\begin{tabular}{|c|c|c|c|c|}
\hline \multirow{2}{*}{$\begin{array}{l}\text { Objek } \\
\text { Wisata }\end{array}$} & \multicolumn{2}{|r|}{ Faktor Internal } & \multicolumn{2}{|c|}{ Faktor Eksternal } \\
\hline & $\begin{array}{c}\text { Potensi/ } \\
\text { Kekuatan }\end{array}$ & $\begin{array}{c}\text { Kendala/ } \\
\text { Kelemahan }\end{array}$ & $\begin{array}{c}\text { Peluang/ } \\
\text { Kesempatan }\end{array}$ & $\begin{array}{c}\text { Tantangan/ } \\
\text { Ancaman }\end{array}$ \\
\hline $\begin{array}{l}\text { Ke } 16 \\
\text { objek } \\
\text { wisata di } \\
\text { Kabupa } \\
\text { ten } \\
\text { Serdang } \\
\text { Bedagai }\end{array}$ & 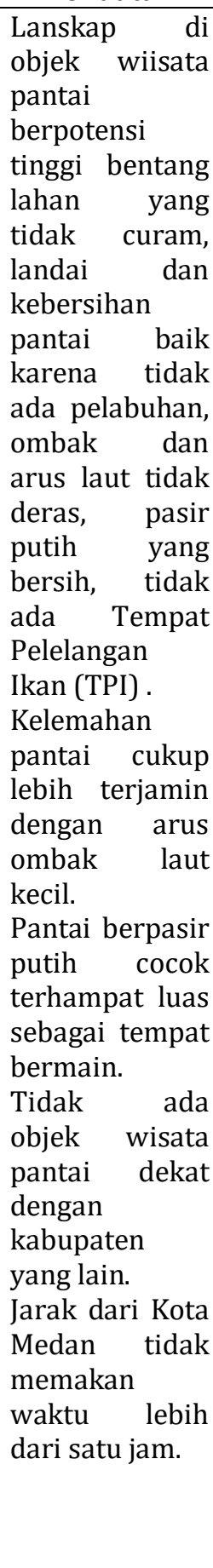 & $\begin{array}{l}\text { Lokasi objek wisata yang } \\
\text { banyak dan berdekatan } \\
\text { dengan wahana bersamaan, } \\
\text { hampir tidak ada pembeda } \\
\text { dari objek wisata yang ada } \\
\text { dengan objek wisata di tempat } \\
\text { lain atau kelangkaan tidak } \\
\text { ditemukan. } \\
\text { Pembeda atau kelangkaan } \\
\text { objek yang satu dengan } \\
\text { lainnya tidak ditemukan } \\
\text { membuat pengunjung tidak } \\
\text { mempunyai opini lokasi mana } \\
\text { yang dituju. air laut kurang } \\
\text { Kebersihan air } \\
\text { baik untuk dijadikan mandi- } \\
\text { mandi karena banyak lumpur. } \\
\text { Kurangnya ha hubungan } \\
\text { kerjasama antara pengelola, } \\
\text { pemerintah daerah dengan } \\
\text { masyarakat. } \\
\text { Tidak adanya pelayanan } \\
\text { pariwisata pantai yang } \\
\text { professional. } \\
\text { Tidak adanya papan petunjuk } \\
\text { ke lokasi. } \\
\text { Kurang ada campur tangan } \\
\text { dari PEMDA Kabupaten dan } \\
\text { Kecamatan seperti promosi. } \\
\text { Tidak ada lokasi objek wisata } \\
\text { yang dikelola langsung } \\
\text { PEMDA setempat. } \\
\text { Terlalu banyak kutipan- } \\
\text { kutipan yang terjadi di lokasi. } \\
\text { Prasarana jalan masuk ke } \\
\text { lokasi kurang memadai } \\
\text { seperti kurang baik, sempit, } \\
\text { dan melintasi perkampungan } \\
\text { yang dekat ke jalan. } \\
\text { Tidak adanya sarana } \\
\text { transportasi umum hingga ke } \\
\text { lokasi menyulitkan. } \\
\text { Kurangnya pengetahuan } \\
\text { pengelola dan masyarakat } \\
\text { tentang ekowisata. }\end{array}$ & 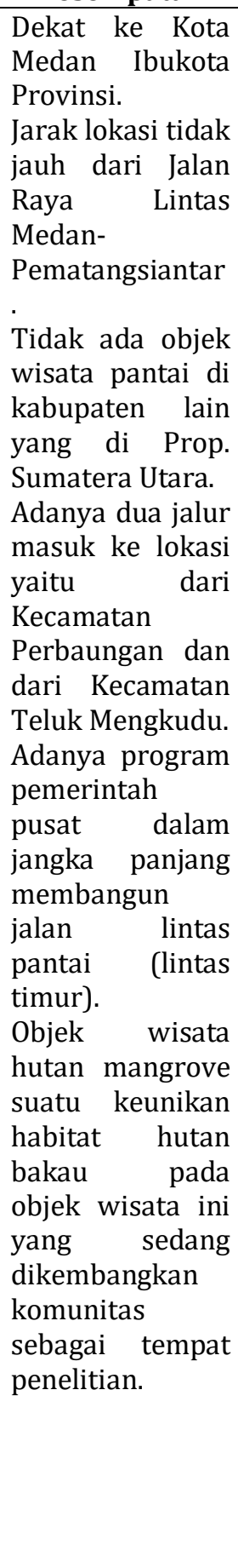 & 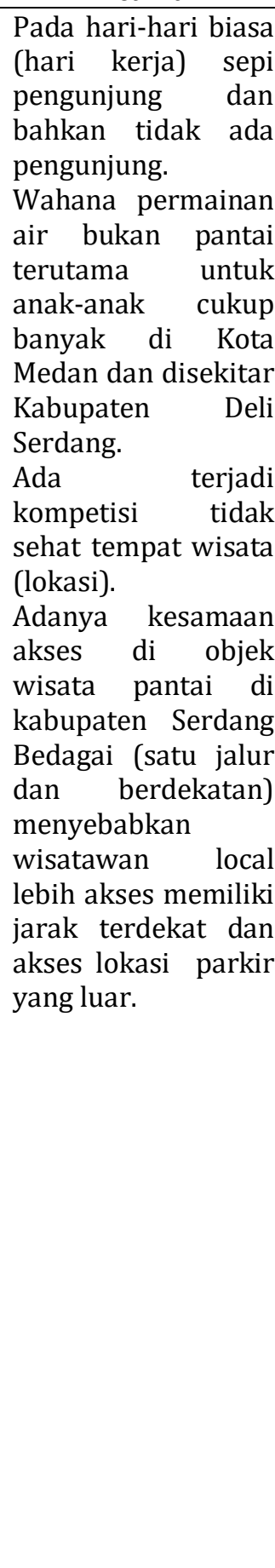 \\
\hline
\end{tabular}




\section{Profit Wisatawan Berkunjung Ke Objek Wisata Pantai Kabupaten Serdang Bedagai}

Wisatawan yang berkunjung ke lokasi wisata pantai ternyata lebih banyak laki-laki, namun perbedaannya tidak signifikan dengan pengunjung perempuan yaitu laki-laki 53\%, dan hanya perempuan $47 \%$, seperti pada Tabel 8. Hasil pengamatan maupun wawancara yang dilakukan pada pihak Kepala Desa, Petugas di lokasi objek wisata dan masyarakat, pengunjung selalu berpasangan, pengunjung yang datang sendiri-sendiri sangat jarang sekali ditemukan, dan paling banyak datang dalam bentuk rombongan (group) seperti keluarga atau anak-anak sekolah paling banyak dalam rombongan.

Berdasarkan hasil pengamatan (observasi) kunjungan wisatawan ke objek wisata pantai yang ada hanya pada harihari libur dan hari besar, pada hari-hari biasa atau hari kerja hampir boleti dikatakan tidak ada wisatawan yang berkunjung ke lokasi wisata atau sepi pengunjung, hanya berkisar kurang dari 20 pengunjung, dan bahkan ada di beberapa lokasi wisata kosong tidak ada pengunjung. Ini merupakan suatu tantangan

Usia wisatawan, ternyata wisatawan yang berkunjung ke lokasi wisata pantai lebih banyak berusia antara 20 tahun sampai kurang dari usia 50 tahun. Banyak wisatawan yang datang berkunjung ke lokasi objek wisata pantai berpendidikan SMA (56\%), disusul yang berpendidikan perguruan tinggi (39\%). Berarti pengunjung adalah kaula muda berusia 2030 tahun (25\%) kurang tertarik bekunjung ke objek wisata pantai ini, diantaranya berpendidikan SMA (19\%), sedangkan berpendidikan Perguruan Tinggi cukup sedikit (4\%). Menurut wawancara dengan petugas lokasi pantai, dan masyarakat setempat, pada hari-hari tertentu ada, terutama selesai ujian yang berkunjung dari luar daerah yaitu murid SD datang secara rombongan dengan bus carteran.
Pengunjung umumnya berasal dari luar Kabupaten Serdang Bedagai (9\%) yaitu dari Kota Medan (59\%), pengunjung dari luar Propinsi Sumatera Utara jumlah sangat rendah sekali, seperti yang terlihat pada Tabel 10 dengan demikian objek wisata pantai Kabupaten Serdang Bedagai masih pada tingkat regional.

Pengunjung dari luar Propinsi Sumatera Utara pun ada masih tergolong rendah hanya 15\%. Gambaran dari Tabel 9 dan Tabel 10 memperlihatkan potensi objek wisata pantai di Kabupaten Serdang Bedagai cukup berpotensi dan cukup baik untuk dikembangkan, karena sudah dikenal ditingkat regional, namun masih diperlukan pembenahan.

Wisatawan yang terbanyak datang berprofesi sebagai buruh (35\%), kemudian pedagang $(23 \%)$ dengan berpendapatan antara Rp 2 juta sampai Rp 3 juta (41\%). Penduduk yang berpenghasi.lan lebih tinggi lagi terlihat kurang berminat datang ke lokasi objek wisata pantai di Kabupaten Serdang Berdagai hanya mencapai 26\% saja. Untuk itu, diperlukan suatu terobosan baru dengan menampilkan berbagai atraksi atau kelangkaan agar wisata berminat berkunjung ke lokasi wisata pantai di Kabupaten Serdang Bedagai sehingga terhindar dari kekosongan pengunjung pada saat hari biasa. Dengan demikian pengelola objek wisata tidak merugi.

\section{Potensi Objek Wisata Pantai Kabupaten Serdang Bedagai}

Secara umum, ke 16 lokasi objek wisata pantai yang dimiliki Kabupaten Serdang Bedagai mencapai 91\% datang dari luar Kabupaten Serdang Bedagai. Pengunjung yang datang menuju ke salah satu objek bukan diakibatkan adanya kelangkaan atau penyajian atraksi yang menonjol menarik perhatian, melainkan hanya informasi-infonnasi dari pengunjung yang pernah berkunjung, atau digiring seseorang sebagai "petugas" untuk mengarahkan ke lokasi objek. Potensi 
objek wisata pantai yang dimiliki Kabupaten Serdang Bedagai masih pada tingkat sedang karena hampir tidak ada pembeda antara objek wisata yang satu dengan yang lain.

Peta lokasi objek wisata tidak ada terpampang dengan jelas di jalan sebagai pintu masuk ke lokasi. Penunjuk arah lokasi barn terlihat setelah berada di gerbang masuk ke lokasi, dan itupun sangat sederhana dan kecil sehingga menyulitkan pengunjung melihatnya.

Theme Park. Objek wisata Theme Park berada di tepi pantai Desa Pantai Cermin Kanan Kecamatan Pantai Cermin. Objek wisata yang satu ini menjadi salah satu ikon pariwisata di Kabupaten Serdang Bedagai selain Pulau Berhala dan merupakan objek wisata pantai yang memiliki potensi paling tinggi dari semua objek wisata pantai yang ada, karena wahana bermain lebih lengkap, memiliki pemenuhan kebutuhan fisik dan sosial yang lengkap, mudah dijangkau, pengunjung dapat langsung dengan bebas melihat laut lepas sehingga berpotensi tinggi. Kelangkaan yang ada di lokasi ini cukup banyak wahana atraksi yang disajikan. Berbagai permainan air yang tersedia, dan berbagai permainan lain ada di lokasi itu, yaitu karaoke, games serta bagi-bagi hadiah bagi para pengunjung yang datang. Pengunjung bebas berkaraoke ria menunjukkan kernampuannya di ruangan yang tersedia yang ditata sedernikian rupa. Pengunjung juga dapat bermain voli pantai. jetski, kayak, banana boat yakni boat yang berbentuk seperti pisang. Persis di tengah lokasi Theme Park terdapat pantai putih bersih, menarik untuk dinikmati.

Klang berada di Desa Naga Lawan Kecamatan Perbaungan, jalur masuk ke lokasi lebih dekat dari Desa Mata Pao Kecamatan Teluk Mengkudu melinlasi jalan ke objek wisata Sialang Buah dan Sentang, dan dari Desa Pantai Cermin Kanan di Kecamatan Pantai Cermin melintasi jalan menuju ke objek wisata pantai Mutiara, Gudang Garam, Wong Rame, Permai Indah, Lestari, dan Theme Park sehingga dapat mempengaruhi minat pengunjung untuk tidak sampai ke tujuan ke Klang. Di lokasi objek wisata ini memiliki lapangan parkir luas dan ditanami tumbuhan yang sudah tua dan rindang yang dapat menambah kesejukan udara sekitar membuat pengunjung betah berlama-lama. Namun pemenuhan kebutuhan fisik dan sosial kurang lengkap dan sulit untuk dijangkau, pengunjung tidak dengan lepas bebas melihat laut sebagai akibat ada gubung-gubuk penghalang pandangan. Hasil wawancara pengunjung rarnai hanya diakhir pekan, dan pada hari-hari libur yang datang dari berbagai daerah seperti Labuhan Batu, Tanjung Balai, Asahan, Tebing Tinggi, Medan dan Tanah Karo dengan mobil pribadi dan bus umum yang sengaja mereka carter atau sewa dari daerah masing-masing.

Kelangkaan yang terdapat di daerah objek wisata ini sehingga banyak dikunjungi karena adanya sebuah sumur air tawar tidak berada jauh dari bibir pantai, hanya berjarak 90-an meter yang bernilai sejarah. Menurut keterangan dari masyarakat setempat dan para pengunjung yang hadir, sumur ini dikatakan surnur ajaib (dis. Sumur berkah/sumur penyembuhan) dengan kedalaman satu setengah meter tetapi rasa air dalam sumur tersebut tawar seperti air gunung dan tidak pernah habis atau kering walaupun setiap para pengunjung yang datang ke lokasi itu selalu membawa atau mengambil air dari sumur tersebut dengan memakai jerigen atau botol. Di pantai Klang pengunjung dapat menikmati indahnya pemandangan pantai dengan pasirnya yang putih bagai kristal dan melihat deru ombak serta menikmati terpaan angin laut sehingga menghilangkan kepenatan. Di kawasan Pantai Kiang tersedia pondok-pondok kecil bagi pengunjung, untuk dapat memakai pondok harus membayar antara Rp 9.000 
sampai Rp 20.000, menurut ukuran besar pondok yang disewa. Pondok biasanya digunakan sebagai tempat barang-barang yang dibawa, tempat istirahat dan berteduh bila letih berjalan mengitari pantai atau sehabis mandi di laut. Para pengunjung yang datang ke lokasi objek wisata ini selalu terlihat berbasahbasahan. Anak-anak dapat berenang dan bennain bersama riak ombak di tepi pantai yang telah tersediakan di kawasan tepi pantai khusus untuk anak-anak dan lebih mengasyikkan dalam menikmati mandi air laut dan berenang di sekitar tepi pantai. Masyarakat sekitar pantai dan pengelola menyediakan ban untuk disewa dengan harga Rp. 3.000 sampai Rp 5.000. Bila berada di pantai Klang pengunjung tak ingin cepat-cepat meninggalkan lokasi tersebut, betah bermain dengan ombak atau duduk-duduk santai di pondok yang tersedia di lokasi kawasan pantai terdapat sejumlah makanan ringan seperti mie goreng, ayam goreng, pecal, sate kerang dan bermacam jajanan ringan, hasil sajian warga masyarakat sekitar pantai. Salah satu daya tank para pengunjung datang ke lokasi Pantai Kelang karena para penjual makanan, penyewa ban dan penyewa pondok pantai ramah dalam melayani setiap para pengunjung, dan selalu berpesan agar para pengunjung dapat memberitahukan keadaan wisata pantai itu kepada tetangga, famili lainnya agar datang kesana untuk menikmati wisata di Pantai Klang.

Mutiara, Objek wisata Mutiara berada di tepi pantai Desa Kota Pari Kecamatan Pantai Cennin, memiliki daya tarik tersendiri karena letaknya di areal hutan bakau (mangrove) dan lingkungannya terlihat asri. Pengunjung objek wisata ini dapat melihat tempat berkembangbiaknya ikan laut dan kepiting di dalam air di antara akar-akar pohon bakau. Tersedia restoran dengan sajian ikan laut (sea food) dan pondok-pondok santai. Kelangkaan dan atraksi yang terdapat di lokasi objek wisata ini yang menjadi daya tarik hampir tidak ada bedanya dengan di lokasi yang lain.

Lestari, berada di tepi pantai Desa Pantai Cermin Kanan Kecamatan Pantai Cennin sebagai objek wisata pantai memiliki daya tank tersendiri yaitu adanya ornament gapura bercirikhaskan bali. Bila kita berada di lokasi serasa berada di pulau Bali.

Gudang Garam, objek wisata ini berada di Desa Kota Pari Kecamatan Pantai Cermin Di pantai Gudang Garam tersedia fasilitas penginapan (hotel) dilengkapi AC, restoran seafood, karaoke/musik dan pondok-pondok santai serta beberapa kolam pancing. Hamparan pasir putih di sepanjang pantai di lokasi objek wisata ini sangat menarik dan dapat dijadikan tempat bermain volley pantai serta permainan pantai lainnya.

Permai Indah, terletak di pinggiran pantai Desa Kota Pari Kecamatan Pantai Cermin. Objek wisata Pondok Permai sudah sangat dikenal oleh masyarakat kota-kota besar di Sumatera Utara bahkan di Indonesia. Restorannya yang berada sangat dekat dengan bibir pantai mengundang minat pengunjung untuk sering datang ke objek wisata Pondok Permai ini.

Sialang Buah, Objek wisata pantai Sialang Buah berada di Desa Sialang Buah Kecamatan Teluk Mengkudu, berjarak 60 $\mathrm{Km}$ dari kota Medan atau $9 \mathrm{Km}$ dan Sei Rampah (ibukota Kabupaten Serdang Bedagai) melewati rute Medan Tebing Tinggi. Menurut hasil wawancara dengan penduduk sekitar, objek wisata pantai ini sudah cukup lama dikembangkan, dan awalnya merupakan objek wisata primadona. Kurangnya minat wisatawan datang ke lokasi ini, karena terlalu dekat permukiman, dan ada terdapat tempat pelelangan ikan sehingga terkesan kumuh jalan menuju lokasi kurang terawat.

Wong Rame, terletak di pinggiran pantai Desa Kota Pari Kecamatan Pantai Cermin. Objek wisata Wong Rame (bahasa Jawa) artinya banyak orang yang datang ke 
objek ini sehingga diberi nama Wong Rame. Memang di objek ini cukup aman dan sejuk, namun tidak ada pembeda dari objek wisata yang ada di Kecamatan Pantai Cennin ini. Dan hasil wawancara dengan masyarakat dan pengunjung, mereka berkunjung hanya dengar informasi teman yang sudah pemah ke lokasi ini, dan diajak dan ditunjuk penduduk yang peduli dengan wisata ini.

Sri Mersing, terletak di Desa Kuala Lama Kecamatan Pantai Cermin. Lokasi cukup baik situasi yang aman dan sejuk dengan pepohonan yang tersusun rapi, lapangan parkir cukup luas, akibat dan berada di tengah dan pengunjung kurang mengetahui adanya lokasi yang baik. Romantis Bay, terletak di Desa Kuala Lama Kecamatan Pantai Cermin. Lokasi objek wisata ini mempuyai atraksi tersendiri yaitu adanya kelambu-kelambu berwarna pink yang dapat menarik perhatian pengunjung. Namun hasil wawancara penulis dengan pengunjung tidak begitu tertarik, dan kutipan-kutipan banyak.

Cemara Ketnbar, terletak di desa Kuala Lama Kecamatan Pantai Cermin. Lokasi objek wisata ini cukup baik, hanya jalan masuk ke lokasi tidak baik, kurang terawat dan sempit.

Kuala Putri, Pantai Kuala Putri terletak di desa Kuala Lama Kecamatan Pantai Cermin. Di objek wisata ini pengunjung dapat berbaur dan melihat kehidupan masyarakat nelayan. Disini terdapat restoran seafood, pondok-pondok santai dan panggung hiburan serta kolam pancing.

Pematang Mantik, berada di Desa Kuala Lama Kecamaan Perbaungan sebagai objek wisata berpotensi sedang. Nipah Indah berada di Desa Kuala Kama Kecamaan Perbaungan sebagai objek wisata berpotensi sedang diakibatkan lingkungan sekitar tidak menunjukkan sebagai lokasi untuk dikunjungi dan lagi pula dekat ke sungai yang kurang mendukung karena kotor air sungainya dan udara sekitar agak berbau lumpur sungai.

Hutan Mangrove atau wisata Pantai Kampoeng Nipah sebagai objek wisata Mangrove berada di Desa Kuala Lama Kecamatan Pantai Cermin merupakan objek wisata yang rnasih langka dihati masyarakat Indonesia. Objek wisata hutan mangrove merupakan objek wisata khusus penelitian, dan dikelola masyarakat komunitas. Jadi kurang mendapat perhatian.

Sentang berada di Desa Sentang Kecamatan Teluk Mengkudu dan merupakan objek wisata pantai berpotensi tingkat rendah sebagai akibat dari kurang terawat, dan jalan masuk menuju lokasi kurang baik dan pengelolaan pun kurang baik, sehingga pengunjung juga tidak ada berkunjung ke lokasi ini. Lokasi ini yang paling dekat ke jalan lintas raya Medan Tebing Tinggi, dengan waktu tempuh paling singkat.

\section{Landskap Objek Wisata Pantai Kabupaten Serdang Bedagai}

Landskap Objek Wisata Pantai merupakan suatu daya tarik yang penting dan paling utama. Kelangkaan yang terdapat dari suatu objek merupakan objek yang dicari para calon wisatawan. Hasil observasi dan hasil perhitungan observasi terhadap terhadap landskap yang ada di 16 lokasi objek wisata pantai di Kabupaten Serdang Bedagai pada dasarnya mempunyai potensi daya tarik landskap berpotensi tingkat sedang, bagus seperti hasil wawancara dengan penduduk dan pemerintah setempat.

Bukit yang rendah dan berombak, bukit di kaki gunung atau dasar lembah yang datar atau bahkan merupakan ciriciri landscape yang menarik - berbentuk Bukit terjal dan Ngarai/lereng yang curam; berbentuk kerucut gunung api atau polapola erosi/abrasi oleh angin yang menarik atau variasi ukuran dan bentuk lahan atau ciri-ciri detail yang dominan Bergelombang tidak ada ditemukan. Relief 
vertikal yang tinggi yang ditunjukkan adanya puncak yang ditunjukkan adanya singkaban batuan raksasa atau variasi permukaan yang menakjubkan - Datar hingga landai yang ditemukan.

Ketiga aspek landskap dan objek wisata pantai ini merupakan aspek pendukung potensi perkembangan wisata yang ada di Kabupaten Serdang Bedagai berpotensi tinggi karena bentang lahang cukup mendukung karena tidak curam dan pantainya landai sehingga tidak pengunjung tidak ada rasa was-was, terutama anak-anak yang bermain pasir pantai yang putih. Aspek kedua pendukung wisata adalah kebersihan pantai tidak dipengaruhi kapal-kapal, tempat pelelangan ikan tidak ada, hanya di pantai wisata Sri Mersing yang ada kapalkapal nelayan penduduk setempat tetapi tidak terlalu banyak. Sungai yang masuk ke pantai juga tidak banyak sehingga pantai tidak banyak pengaruhi, hanya di pantai wisata Sialang Buah yang air pantainya berlumpur dan banyak dipengaruhi Tempat Pelelangan Ikan, Pabrik dan sungai yang banyak membawa lumpur, dan juga pantai Sialang Buah ini sudah terlalu dekat dengan pemukiman penduduk.

Ombak pantai dan arus pantai di lokasi objek wisata pantai di Kabupaten Serdang Bedagai ini, tidak ditemukan arus balik yang dapat membahayakan pengunjung, sehingga para pengunjung tetap tenang terutama yang membawa anak-anak. Menurut hasil wawancara peneliti dengan penduduk setempat dan bahkan Kepala Desa Pantai Cermin Kanan tidak pernah terjadi kecelakaan akibat arus dan ombak pantai.

Aspek landskap dari objek wisata pantai yang ada di Kabupaten Serdang Bedagai sebagai aspek pendukung potensi perkembangan wisata ada sebanyak 8 aspek berpotensi rendah. Ketersediaan Air Bersih yang ada tidak memadai dan berupa air dalam tong (drum) terkadang tidak tersedia airnya untuk membersihkan badan pengunjung dan pengunjung yang hendak menggunakannya dikutip lagi bayaran, demikian juga untuk penggunaan toilet harus membayar.

Penggunaan Lahan yang dimaksukan dalam penelitian ini adalah lokasi objek wisata pantai adalah pengelola objek wisata yang ada dikelolakan pihak swasta atau pribadi, tidak ada yang dikelola PEMDA. Pihak PEMDA hanya menerima biaya pajak, sebaiknya objek wisata ini dikelola pihak PEMDA atau setidaknya ada campurtangan pihak PEMDA, agar tiap objek wisata melakukan pembagian kegiatan kelangkaan ditiap masing-masing objek sehingga terdapat pembedaan kegiatan lokasi di objek yang satu dengan yang lain. Pengunjung dapat dengan pasti tujuan lokasi yang diinginkannya.

Variasi warna yang halus dan kontras, umumnya bersifat mati, tidak terdapat berbagai jenis warna, ada pertentangan warna dari tanah, batu dan vegetasi, tetapi bukan unsur keindahan yang dominan, sehingga kombinasi jenis warna yang beragam atau wama yang hidup atau pertentangan yang indah dari warna tanah, vegetasi dan air tidak ada ditemukan meeri pemandangan kualitas gambar sekitar kurang memberi kesan yang tinggi

Keindahan pantai sebagai objek wisata yang sangat menarik bila di lokasi terdapat pulau atau gunung laut, terdapat karang, terdapat biota laut, view dapat dilihat dari atas, tinggi ombak antara 1-2 m tenyata di lokasi objek wisata Kabupaten Serdang Bedagai tidak ditemukan, yang ditemukan hanya terdapat pasir di tepi pantai, sehingga potensi objek ditinjau dari aspek ini menjadikan berpotensi. Untuk itu perlu dikembangkan objek wisata ekowisata.

\section{Transportasi dan Aksesibilitas Ke Objek Wisata Pantai Kabupaten Serdang Bedagai}

Betapapun indahnya landskap suatu objek wisata, bila sarana transportasi tidak mendukung untuk dapat mencapainya 
tentu tidak dapat memberikan hasil yang memauaskan. Demikian juga aksesibiltas prasarana kurang baik kondisinya juga dapat menghambat dan merupakan suatu tantangan untuk dapat berkembang. Secara umum nilai potensi dari transportasi dan aksesibilitas berpotensi.

Transportasi sebagai aksesibilitas ke objek wisata yang dimiliki berupa: 1) Prasarana jalan menuju ke objek wisata kurang-terawat dengan baik dan sempit melalui permukiman penduduk yang dekat dengat jalan, dan 2) Waktu tempuh menuju lokasi objek wisata menjadi lama akibat dari jalan yang sempit dan banyak penduduk yang rumahnya dekat ke jalan. Sarana transportasi dan angkutan ke objek wisata menuju lokasi tidak tersedia sehingga pengunjung harus berkenderaan sendiri, dan jarak dari ibukota kabupaten ke lokasi objek wisata mencapai waktu tempuh lebih dari satu jam jarak tempuh lebih, demikian juga dari Kota Medan. Objek wisata Sialang Buah dan Sentang lebih dekat ke ibukota kabupaten, pengunjung kurang tertarik berkunjung, karena masyarakat dari Kabupaten Serdang Bedagaipun jumlahnya sangat kecil yang berpariwisata pantai.

\section{Persepsi Wisatawan dan Masyarakat}

Hasil wawancara pada wisatawan mereka kurang tertarik dan enggan untuk datang pada waktu berikut, bila tidak diajak teman atau rombongan. Terhadap objek wisata pantai ini, Pantai sangat baik untuk dijadikan ekowisata, selain menjaga keselamatan pantai dan daratan juga dapat menjaga habitat satwa laut seperti ikan, terumbu karang. Ternyata pengetahuan wisatawan dan masyarakat belum mengetahui tentang arti ekowisata pantai dan belum pernah mendengamya. Akibat belum memahami dan baru mendengamya sehingga masyarakat berpendapat kurang setuju untuk lokasi objek wisata dikemas menjadi ekowisata, sedang wisatawan setuju dengan melibatkan masyarakat. Terlihat juga sekarang, terhadap objek wisata pantai, masyarakat sekitar kurang respek dan tidak ada keterlibatan masyarakat berdampak kurang memperlihatkan keberadaan objek.

Keterlibatan dari PEMDA dalam mengelola objek wisata pantai ini kurang menunjukkan perhatian, mereka terlihat hanya dalam pemberian ijin usaha, sedang untuk pengembangan masih kurang terlihat, seperti tidak adanya papan reklame petunjuk jalan ke lokasi objek wisata pantai.

Persepsi pengunjung dan masyarakat terhadap objek wisata pantai di Kabupaten Serdang Bedagai tentang pengetahuan ekowisata, mereka belum pernah mendengarnya dan masih baru tahu dan mendengarnya. Para pengunjungpun demikian hanya $62 \%$ yang baru mengerti dan mengetahuinya, dari masyarakat mencapai $\quad 77 \%$. Adapun persepsi maasyarakat terhadap objek keinginan wisatawan bermotivasi hanya untuk pelepas lelah dan kepenatan. Lokasi ini juga banyak digunakan untuk kegiatan rapat-rapat dari kantor-kantor, bersenangsenang. Kenderaan yang digunakan kenderaan pribadi atau bus carteran. Situasi pantai cukup baik, tapi kurang cocok untuk kegiatan penyelaman atau bermandi-mandi, dan tidak pernah terjadi kecelakaan memakan korban karena ombak air laut tidak besar dan tidak ada arus balik. Kekurangannya kebersihanpantai kurang terawat sepertinya tidak ada petugas kebersihan pantai sehingga terlihat kumuh. Demikian pula wahana permain sangat terbatas, perlu ditambah terutama atraksi yang dapat menarik perhatian masyarakat pengunjung.

\section{SIMPULAN}

Hasil penelitian melalui pemberian scoring terhadap aspek variabel dan objek wisata pantai ada sebanyak 17 lokasi objek yang terdapat di Kabupaten Serdang Bedagai. Objek wisata pantai Pulau Berhala tidak ikut dianalisa karena belum 
merupakan objek wisata pantai untuk umum, karena daerah khusus penangkaran penyu dan kawasan TNI dan walaupun daerah ini cocok untuk objek ekowisata. Dari ke 16 objek wisata pantai ini secara umum terkelompok berpotensi sedang dan dapat dikelompokkan berdasarkan potensi yang dimiliki objek wisata pantai kedalam 3 kelompok yaitu: Pertama, menurut urutan potensi yang dimiliki di lokasi objek wisata pantai yang: a) Berpotensi tinggi ada di 8 lokasi: 1) Theme Park, 2) Klang, 3) Sialang Buah, 4) Lestari, 5) Permai Indah, 6) Gudang Garam, 7) Mutiara, 8) Wong Rame; b) Berpotensi sedang ada di 7 lokasi: 1) Romantis Bay, 2) Sri Mersing, 3) Cemara Kembar, 4) Pematang Mantik, 5) Kuala Putri, 6) Nipah Indah, 7) Hutan Mangrove (Kampung Nipah), dan c) Berpotensi rendah hanya di 1 lokasi: 1) Sentang.

Kedua, menurut Lansdkap objek wisata pantai berpotensi yang dimiliki: a) Berpotensi tinggi ada di 2 aspek: 1) Bentang Lahan, dan 2) Kebersihan pantai; b) Berpotensi sedang ada di 12 aspek: 1) Ketersediaan air bersih/tawar, 2) Bentuk penggunaan lahan, 3) Keselamatan pantai tepi laut, 4) Warna, 5) Vegetasi, 6) Pemandangan sekitar, 7) Keindahan pantai, 8) Keragaman atraksi/objek, dan 9) Pemandangan; c) Berpotensi rendah ada di 2 aspek: 1) Kelangkaan, dan 2) Kepemilikan lahan.

Ketiga, Menurut Transportasi sebagai Aksesibilitas ke objek wisata yang dimiliki: a) Berpotensi tinggi ada di 2 aspek: 1) Prasarana jalan menuju ke objek wisata, dan 2) Waktu tempuh menuju lokasi objek wisata. b)Berpotensi rendah ada di 2 aspek: 1) Sarana transportasi dan angkutan ke objek wisata, dan 2) Jarak dari ibukota kabupaten ke lokasi objek wisata

Keempat, menurut Fasilitas Penunjang Obyek/Fasilitas Pelengkap Obyek/Amenitas di objek wisata yang dimiliki: a) Berpotensi tinggi ada di 2 aspek: 1) Ketersediaan fasilitas pemenuhan kebutuhan fisik wisatawan, dan 2) Ketersediaan fasilitas pemenuhan kebutuhan sosial wisatawan. b).Berpotensi sedan ada di 2 aspek: 1) Ketersediaan fasilitas melenhkapi objek wisata sebagai wahana, dan 2) Kutipan-kutipan yang ada di lokasi objek wisata

\section{DAFTAR PUSTAKA}

Anonim, (1990). Undang-Undang Nomor 9 Tahun 1990 tentang kepariwisataan, Dinas Pariwisata.

Anonim, (2013). Profil Investasi Pariwisata Kabupaten Serdang Bedagai: Kantor pariwisata Kabupaten Serdang Bedagai.

Bintarto, R, (1987). Urbanisasi dan Permasalahannya, Disiapkan Dalam Rangka Kuliah Pada Pusat Penduduk Interpretesi Foto Pasca Sarjana Tingkat II. Yogyakarta: Fakultas Geografi.

Fandeli, C. (2000). Perencanaan Kepariwisataan Alam, Fakultas Kehutanan Universitas Gajah Mada, Yogyakarta.

Hadinoto, K, (2010), Perencanaan Pengembangan Destinasi Pariwisata. Universitas Indonesia Press, Edisi Revisi: Jakarta.

Kusmayadi, dan E. Sugiarto, (2000), Metodelogi Penelitian dalam Bidang Kepariwisataan, PT. Gramedia Pustaka Utama : Jakarta.

Kuswnonagoro, (19990. Pemanfaatan Kawasan Pantai Selatan Daerah Istimewa Yogyakarta Sebagai Obyek Wisata. Universitas Atmajaya Press: Yogyakarta.

Mantra, I, (1999), Langkah-langkah Penelitian Survey Usulan Penelitian dan Laporan Penelitian, Badan Penerbitan Fakultas Geografi UGM: Yogyakarta.

Muta'ali, Lutfi. (2013a). Daya Dukung Lingkungan Dan Wilayah. Badan Penerbit FakultasGeografi. UGM Yogyakarta.

Muta'ali, Lutfi. (2013b). Penataan Ruang Wilayah Dan Kota. Badan Penerbit Fakultas Geografi. UGM Yogyakarta.

Pearce, D.G, (1981), Tourist Development, Longman Inc, New York.

Singarimbun, M. dan S. Effendi. (1989), Metode Penelitian Survai, LP3ES, Jakarta.

Spillane, J, (1994). Pariwisata Indonesia Siasat Ekonomi dan Rekayasa Kebudayaan. Kanisisus, Yogyakarta.

Suartha, N, (1994). Pengaruh Pariwisata Terhadap Lingkungan Sosial Ekonomi masyarakat Desa Batubulan Daerah Tingkat II Gianyar. Tesis S2 Program Pasca Sarjana Universitas Gajah Mada.

Sugiyono. (2003). Statistik Untuk Penelitian. CV Alfabeta, Bandung.

Suharyanto, A. (2017). Meningkatkan Berpikir Kritis Mahasiswa Pada Objek Pariwisata Dengan Menggunakan Pendekatan Langsung Ke Subjek Penelitian, Prosiding Seminar 
Nasional Tahunan Fakultas Ilmu Sosial Universitas Negeri Medan Tahun 2017: 308311.

Sujali, (2009), Geografi Pariwisata dan Kepariwisataan: Edisi Revisi 1. Fakultas Geografi Universitas Gajah Mada. Yogyakarta.

Suwantoro (1997). Dasar Dasar Pariwisata. Andi. Yogyakarta.

Wall, (2009), Tourism: Ekonomic, Physical and Sosial Infact. Logman. London and new York.

Yoeti, H.O.A, (2007), Perencanaan dan Pengembangan Pariwisata, Pradya Paramita: Jakarta.

Badan Perencanaan Pengembangan Daerah (BAPPEDA) Kabupaten Serdang Bedagai, 20132033, Penyusunan Tata Ruang Wilayah
Serdang Bedagai tahun 2010. Sumatera Utara: Pemerintah kabupaten Serdang Bedagai.

Badan Perencanaan Pembangunan Daerah (BAPPEDA) Kabupaten Serdang Bedagai, Sumatera Utara: Badan Pusat Statistik Kabupaten Serdang Bedagai.

Departemen Pariwisata Pos dan Telekomunikasi, 1990. Undang-Undang Republik Indonesia No 9 7'ahhun 1990 tentang Kepariwisataan. Jakarta: Departemen Pariwisata Pos dan Telekomunikasi.

Pemerintah Daerah Tingkat II Serdang Bedagai. 2004. Rencana Umum Tata Ruang. Serdang Bedagai: Bappeda Tingkat II Serdang Bedagai. 